\title{
The Contest Validation of Circuit Training Design to Improve Biomotor Components in Table Tennis Performance
}

\author{
Tomoliyus \\ Faculty of Sport Sciences \\ Universitas Negeri Yogyakarta \\ Yogyakarta, Indonesia \\ tomoliyus@uny.ac.id
}

\author{
Devi Tirtawirya \\ Faculty of Sport Sciences \\ Universitas Negeri Yogyakarta \\ Yogyakarta, Indonesia \\ devi@uny.ac.id
}

\author{
Rumpis Agus Sudarko \\ Faculty of Sport Sciences \\ Universitas Negeri Yogyakarta \\ Yogyakarta, Indonesia \\ rumpis@uny.ac.id
}

\author{
Hasman Alhafiz Arif \\ Faculty of Sport Sciences \\ Universitas Negeri Yogyakarta \\ Yogyakarta, Indonesia \\ hasman.alhafiz2016@student.uny.ac.id
}

\author{
Hary Widodo \\ Faculty of Sport Sciences \\ Universitas Negeri Yogyakarta \\ Yogyakarta, Indonesia \\ hary.widodo2016@student.uny.ac.id
}

\begin{abstract}
Power, agility and endurance are the important biomotor components when evaluating performance in table tennis. The objective of the study is to examine the validation of the contents of the circuit training design with linear loading in the pre-competition period to improve power, endurance, and agility in the performance of table tennis. The research method used the qualitative and quantitative mixed methods. The research subject used was documents. The evaluation techniques with experts were used as data collection method. The Lawshe's formula of Content Validity Ratio (CVR) was used for data analysis. The results of the study showed that there was high content validity. The conclusion from the program circuit training design with linear loading in the precompetition period to improve power, endurance, and agility in table tennis performance is feasible to use.
\end{abstract}

Keywords-circuit training, endurance, agility, power

\section{INTRODUCTION}

Power, agility and endurance are very important components in table tennis performance $[1,2]$. Therefore, it is necessary to improve the biomotor components of power, agility and durability with accurate periodization of time of training design. Training periodization is preferred when training power, agility, and endurance rather than not using the training periodization $[3,4,5,6,7]$. Training periodization is an important part in the preparation of the design of a physical training program $[3,8,9,10,11]$ to achieve a peak performance and reduce the risks of injury and overtraining $[12,13,14,15,16]$. Training periodization is divided into two stages, pre-competition stage and competition stage $[4,17]$. The pre-competition is a stage that focuses on physical power, agility and endurance $(15,17)$ in table tennis performance. The pre-competition periodization with linear loads is safer for beginners and adult athletes to prevent overtraining than undulatory periodized precompetition $[5,6,10,14]$.
Circuit training is one of the average progressive linear loading resistance training methods designed to train and improve the biomotor component including power, agility and endurance $[17,18]$. Some of the research results with low and high intensity of the circuit training program can increase power, agility and endurance $[19,20,21,22,23,24$, $25,26,27,28,29]$, but the result of the circuit training program with low and high intensity is not still optimal to improve power, agility and endurance for beginners and adult athletes of table tennis in the pre-competition stage especially in table tennis performance. Hence, the researcher aims to develop a circuit training program of linear loading with average intensity on the pre-competition stage to improve power, agility and endurance in table tennis performance.

Validity is a central issue in the process of the product design development. Validity illustrates the extent to which the design of circuit training program is accurate to improve power, agility and endurance. There are three types of validity which are; content validity, criterion validity, and construct validity [30]. The content validity tests are often used in the early stages of the process of the product design development.

The objective of this study is to examine the validation of the contents of the circuit training design with linear loading in the pre-competition period to increase power, agility and endurance in table tennis performance.

This article will present research methods, results, discussion, and conclusions while focusing on validating the contents of the circuit training design with linear loading to improve biomotor components of table tennis performance.

\section{METHOD}

The Qualitative and quantitative mixed methods were applied during the research. Documents were used as the research subject. The evaluation techniques with experts were used as the data collection method. Lawshe's formula of Content Validity Ratio (CVR) was used for data analysis. 
CVR $=($ ne-N/2) / $(\mathrm{N} / 2)$, where CVR is the content validity ratio, ne is the number of panelists who answered "important," $\mathrm{N}$ is the total number of panelists.

\section{III.RESULT}

Based on the study of journal documents and textbooks, drafts of circuit design with linear loading have been performed on pre-competition periodization of power, agility and endurance in table tennis performance. Then the draft circuit training program is assessed by five CVR experts. The results are shown on table 1.

TABLE I. EXPERT ASSESSMENT RESULTS ON THE LINEAR LOADING OF CIRCUIT TRAINING DESIGN.

\begin{tabular}{|c|c|c|c|c|c|c|c|}
\hline \multirow{2}{*}{ No } & \multirow{2}{*}{ Factor assessed } & \multicolumn{5}{|c|}{ Expert } & \multirow{2}{*}{$\begin{array}{l}\text { CVR } \\
\text { Value }\end{array}$} \\
\hline & & 1 & 2 & 3 & 4 & 5 & \\
\hline 1 & $\begin{array}{l}\text { The circuit training } \\
\text { intensity corresponding } \\
\text { with the ability of the } \\
\text { beginner athletes }\end{array}$ & 1 & 1 & 1 & 1 & 1 & 1.00 \\
\hline 2 & $\begin{array}{l}\text { Training volume } \\
\text { corresponding with the } \\
\text { ability of the child }\end{array}$ & 1 & 1 & 1 & 1 & 1 & 1.00 \\
\hline 3 & $\begin{array}{l}\text { The physical movement } \\
\text { of each post } \\
\text { corresponding with the } \\
\text { power, endurance and } \\
\text { speed }\end{array}$ & 1 & 1 & 1 & 1 & 1 & 1.00 \\
\hline 4 & $\begin{array}{l}\text { Increasing linear load } \\
\text { corresponding with the } \\
\text { ability of athlete }\end{array}$ & 1 & 1 & 1 & 1 & 1 & 1.00 \\
\hline 5 & $\begin{array}{l}\text { Resting time between } \\
\text { circuits corresponding } \\
\text { with training objectives }\end{array}$ & 1 & 1 & 1 & 1 & 1 & 1.00 \\
\hline 6 & $\begin{array}{l}\text { The number of posts } \\
\text { corresponding with the } \\
\text { purpose of the exercise }\end{array}$ & 1 & 1 & 1 & 1 & 1 & 1.00 \\
\hline 7 & $\begin{array}{l}\text { The time of each post } \\
\text { corresponding with the } \\
\text { purpose of the exercise }\end{array}$ & 1 & 1 & 1 & 1 & 1 & 1.00 \\
\hline 8 & $\begin{array}{l}\text { Time periodization of } \\
\text { training is } 8 \text { weeks }\end{array}$ & 1 & 1 & 1 & 1 & 1 & 1.00 \\
\hline
\end{tabular}

Based on the result in table 1, the CVR has a value of 1.00 . The content validation value is high. In other words, the five assessors have a strong similarity in assessing the circuit training design with linear loading on pre-competition periodization to improve power, agility and endurance in table tennis performance. Based on the training programs seen below in table 2 .
TABLE II. CIRCUIT TRAINING DESIGN WITH LINEAR LOADING

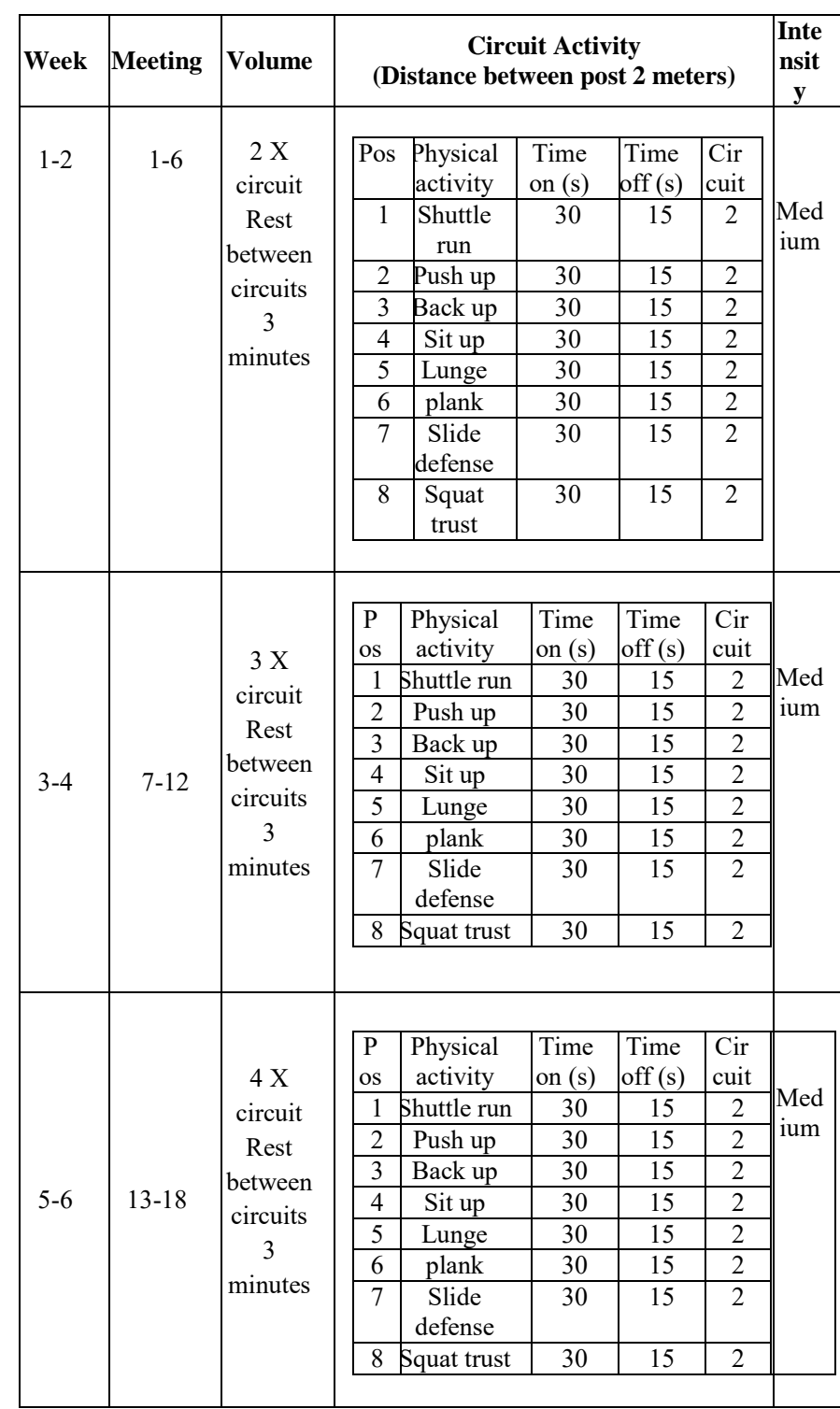

\section{DISCUSSION}

The validation of content is carried out to ascertain whether the contents of the circuit training program design are appropriate and relevant to the training objectives. The validation of content indicates the full attributes range studied and performed by the expert [9]. The estimation of validity can be obtained completely and systematically in assessing items to determine the extent to which they reflect and do not reflect content domains [31,32].

The validation of content is important to be used as a first step in product design development. Validation is often found through $[7,33]$ toward the agreement of assessors and also analyzed quantitatively with the formula of Content Validity Ratio [34, 35].

The results of the quantitative content validity test with Lawshe's formula found that all the items of the five assessors of the circuit training program with linear loading showed the CVR value of 1.00. According to Lawshe [34], the Content Validity Ratio (CVR) through single indicator ranges from -1 to 1 . If the CVR value is closer to 1.00 , the 
value of content validity will be higher. Hence, it can be said that the training with linear loading has an adequate validation or a high validation.

\section{CONCLUSION}

Based on the research results and discussion, it can be concluded that the components of the training program compilation have shown or already has high validation content. Hence, it can be said that the circuit training design with linear loading in the pre-competition period developed is feasible to be used to improve power, agility and endurance in table tennis performance.

The program of the circuit training design with linear loading on periodization is feasible for power, agility and endurance in table tennis performance. To make it more empirically valid, the circuit training design needs to be field tested to determine the effectiveness of the circuit training design.

\section{ACKNOWLEDGEMENT}

This work has been supported by the Faculty of Sport Science, Yogyakarta State University and a physical education teacher and a table tennis sport coach in Indonesia

\section{REFERENCES}

[1] Zagatto, AM, Morel, EA, and Gobatto, CA. Physiological responses and characteristics of table tennis matches determined in official tournaments. The Journal of Strength and Conditioning Research24(4): 942-949, 2010.

[2] Zhang, XD, Zhu, ZQ, Li, WZ, Xiao, DD, and Zhang, YQ. GRF of table tennis players when using forehand attack and loop drive technique. International Journal of Table Tennis Science 8: 15-19, 2013

[3] Baker D Wilson G Carolyn. Periodization: The effect on strength of manipulating volume and intensity. J Strength Cond Res. 1994. 8: 235-242

[4] Bartolomei S Hoffman JR Memi F Stout JR. A comparison of traditional and block periodized strength training programs in trained athletes. J Strength Cond Res. 2014. 28(4): 990-997.

[5] García-Pallarés J, García-Fernández M,Sánchez-Medina L, and Izquierdo M. Performance changes in world-classkayakers following two different training periodization models. Eur J Appl Physiol . 2010. 110: 99-107.

[6] Rhea MR Alderman BL. A meta-analysis of periodized versus nonperiodized strength and power training programs. Res Q Exerc Sport. 2004. 75: 413-423

[7] Rhea MR Ball SD Phillips WT Burkett LN. A comparison of linear and daily undulating periodized programs with equated volume and intensity for strength. J Strength Cond Res. 2002; 16(2): 250-255

[8] Issurin VB.New horizons for the methodology and physiology of training periodization. Sports Med. 2010. 40(3); 189-206

[9] DeVon, H. A., et. al. Psychometric Toolbox for testing Validity and Reliability.Journal of Nursing scholarship. 2007. 39 (2), 155-164.

[10] Painter K, Haff G, Ramsey M, McBride J,Triplett T, Sands W, Lamont $H$, Stone $M$ and Stone $M$. Strength gains: Block versusdaily undulating periodization weight training among track and field athletes.Int J Sports Physiol Perform. 2012. 7: 161-169.

[11] Plisk SS and Stone MH. Periodization strategies.Strength Cond J. 2003. 25: 19-37.

[12] Kiviniemi AM, Tulppo MP, Hautala AJ,Vanninen E, and Uusitalo ALT. Altered relationship between R-R Interval and R-R interval variability in endurance athletes with overtraining syndrome. Scand J Med Sci Sports. 2014. 24: 77-85.

[13] Lorenz DS Reiman MP Walker JC. Periodization: Current review and suggested implementation for athletic rehabilitation. Sports Health. 2010. 2(6):509-518.

[14] Miranda F Simao R Rhea M, et al. Effects of linear vs. daily undulatory periodized resistance training on maximal and submaximal strength gains. J Strength Cond Res. 2011. 25(7): 1824-1830

[15] Michael B. Phillips, Jake A. Lockert, and Lanise D. Rosemond. Tools and benefits of periodization: developing anannual training plan and promoting performance improvements in atletes. 2018. The Journal Volume 20. United States Sports Academy.

[16] Williams TD,Tolusso DV, Fedewa MV, Esco MR. Comparison of Periodized and Non-Periodized Resistance Training of Maximal Strength: A Meta-Analysis. Sport MED. 2017. 47(10):20832100.DOI: $10.1007 /$ S40279-017-0734

[17] Bompa T \& Carlo Buzzichelli. Periodization Training for Sport. 2015.United States: Human Kinetics.

[18] D. Schmidt, K. Anderson, M. Graff, and V. Strutz. "The effect of high-ntensity circuit training on physical fitness," The Journal of Sports Medicine and Physical Fitness. 2016. 56(5), 534-540.

[19] A. Paoli, Q. F. Pacelli, T. Moro et al. "Effects of high-intensity circuit training, low-intensity circuit training and endurance training on blood pressure and lipoproteins in middle-aged overweight men," Lipids in Health and Disease. 2013. 12 (131).

[20] Bounty PL, Campbell BI, Galvan E, Cooke M,and Antonio J. Strength and conditioning considerations for mixed martial arts. Strength Cond J . 2011. 33: 56-67.

[21] Baker DG and Newton RU. Comparison of lower body strength, power, acceleration, speed, agility, and sprint momentum to describe and compare playing rank among professional rugby league players.J Strength Cond Res. 2008. 22: 153-158.

[22] H. Taskin, 2009."Effect of circuit training on the sprint-agility and anaerobic endurance," J Strength Cond Res. 2009. 23(6), 18031810.

[23] S. Romero-Arenas, M. Martinez-Pascual, and P. E. Alcaraz, 2013."Impact of resistance circuit training on neuromuscular, cardiorespiratory and body composition adaptations in the elderly," Aging and Disease. 4(5), 256-263.

[24] Scott M, Scott T, and Kelly VG. The validity and reliability of global positioning systems in team sport: A brief review. J Strength Cond Res.2016. 30: 1470-1490.

[25] Daniel Mayorga-Vega, Jesús Viciana, Armando Cocc. Effects of a Circuit Training Program on Muscular and Cardiovascular Endurance and their Maintenance in choolchildren. Journal of Human Kinetics. 2013. volume 37, 153-160.

[26] Vikesh Kumar .2016. Effect of circuit training program on selected motor abilities among university male. International Journal of Physical Education,Sports and Health. 2016. 3(4), 255-257.

[27] Taşkin H. Effect of circuit training on the sprint-agility and anaerobic endurance. J trength Cond Res. 2009. 23(6), 1803-10. doi: 10.1519/JSC.0b013e3181b3dfc0.

[28] Testa M, Noakes TD, and Desgorces FD. Training state improves the relationship between rating of perceived exertion and relative exercise volume during resistance exercises.2012. J Strength Cond Res: 2990-2996.

[29] Schoenfeld BJ, Ratamess NA, Peterson MD, Contreras B, Sonmez GT, and Alvar BA. 2014. Effects of different volume-equated resistance training loading strategies on muscular adaptations in well-trained men. J Strength Cond Res .2014. 28: 2909-2918.

[30] Embretson, S.E. 2007. Construct Validity: A Universal Validity System or Just Another Test Evaluation Procedure?. Educational Researcher. 2007. 36 (8): 449-455.

[31] Kowsalya, D. N., Lakshmi, H. V., \& Suresh, K. P. Development and Validation of a Scale to assess Emotional Maturity in Mild Intellectually Disabled Children. Language in India. 2012. 12(6).Landis,

[32] Polit, D. F., Beck, C. T., \& Owen, S. V. Is the CVI an acceptable indicator of content validity? Appraisal and recommendations. Research in nursing \& health. 2007. 30(4), 459-467.

[33] Wynd, C. A., Schmidt, B., \& Schaefer, M. A. Two quantitative approaches for estimating content validity. Western Journal of Nursing Research. 2002. 25(5), 508-518.

[34] Wilson, F. R., Pan, W., Schumsky, D. A. Recalculation of the critical values for Lawshe's content validity ratio. Measurement and Evaluation in Counseling and Development. 2012. 45, 197210. doi: $10.1177 / 0748175612440286$.

[35] Polit, D. F., \& Beck, C. T. The content validity index: are you sure you know what's being reported? Critique and recommendations. Research in nursing \& health. 2006. 29(5), 489-497. 